\title{
PISA EVALUATION RESEARCH AND INDEPENDENT MANAGED LEARNING
}

\author{
Akramjon Matkarimov \\ Researcher of Andizhan State University, Andizhan, Republic of Uzbekistan
}

Article DOI: https://doi.org/10.36713/epra4173

\begin{abstract}
The article analyzes process of PISA evaluation research and independent managed learning sources by the helping scientific literatures and media as well.

KEY WORDS: education system, international experience, historical development, syllabus, research results, political education, science, PISA program.
\end{abstract}

\section{INTRODUCTION}

In the ever-changing globalization of globalization processes, the global education system requires rapid development based on social processes. And through education, a new generation of society is able to fulfill its future tasks. There are a number of international programs that determine the quality, level and quality of education in the world, such as PISA (International Student Achievement Assessment Program), PIRLS (International Reading Determination of Reading and Understanding), TIMSS (International Monitoring of Mathematics and Science in the School). They are widely used as criteria for improving the quality of education in developed countries. The objective of the PISA Assessment Survey is to provide the participating States with sufficient information to answer the following questions facing education ministries and agencies:

- Are students prepared enough to take active citizenship in a democratic society at the end of compulsory education?

- Do students have the ability to analyze, substantiate and communicate their ideas and ideas?

- Are students enrolled in school based on current labor market requirements?

- Does the student meet the requirements of lifetime learning?

The PISA Assessment Survey provides both the analysis of school education and the necessary data for other stages of education. In the system of continuous education, such information is important [1, P.9].

\section{METHODS}

In addition to the core competencies of the PISA Assessment, the study also addresses a number of independent learning questions. The basic competences in learning, mathematics and natural sciences are dependent on the learning process, but only the learning process does not provide the necessary conditions for these competencies. Without self-managed education, it is impossible to build a full range of core competencies. The PISA Assessment Study describes self-guided learning as: Students perceptions of learning, the selection and reflection of appropriate learning strategies and methods, and the purposeful, active, and independent use and application of learners' knowledge and skills $[1$, P.14]. In this context, the focus of PISA assessment research is on students' data analysis, motivational preferences and purposefulness, selfcontrol, self-esteem, and educational strategies in various learning situations, types of learning and social relations.

\section{RESULTS AND DISCUSSIONS}

The Decree of the President of the Republic of Uzbekistan "On Measures to Improve the Efficiency of Out-of-School Education in the Public Education System" will help students improve their knowledge and skills in extracurricular activities 


\section{EPRA International Journal of Research and Development (IJRD)}

through: , robotics, mechatronics, engineering and computer software participation in educational tourism, taking courses available in children's technology parks, using the conditions for reading, etc. [2, P.4]. Out-of-school institutions are part of the public education system and are designed to teach.

In the PISA Assessment Survey, the measurement of key competencies does not cover the entire content of education, but covers the basic components. The PISA Assessment Survey is structured on a cyclical basis, which is conducted every three years, and every time one of the main competencies is at the research center. For example, by 2021 , the mathematical support will be at the center of competence assessment research. In this case, half of the research tasks are mathematical. The purpose of this is to provide an opportunity to analyze certain key competencies and related aspects. By 2021, assignments in the core competencies of reading and science will be $50 \%$ of the total. In this case, it also provides sufficient information on the status of the core competencies and their changes over the previous years [3, P.2].

Assessment tasks include three core competencies set out in the PISA Assessment Research Regulation, and the tasks will be developed by an expert group led by an international consortium. These tasks will be reviewed by experts from the PISA Assessment States, who will be trained a year ago. The study also uses specimens used in previous years [3, P.18].

The International Assessment Survey of the Third International Mathematics and Science Study (TIMMS Third International Mathematics and Science Study), conducted since 1995, is conducted every four years by the IEA. This study is conducted in elementary education, in der Secundarstufe I und II on mathematics and natural sciences. The third International Math Survey is the third International Math Study (FIMS, 1964, 12 countries); Conducted as a continuation of the First and Second International Science Studies (1968-1972 and 1982-1986). This international evaluation program is now called the International Quality of Mathematical and Natural Sciences TIMMS (Trends in International Mathematics and Science Study) [3, p.16].

PISA Assessment Research tasks can be structured in many different ways, including graphic images, pictures, texts, and formulas. Almost half of the tasks consist of tasks with several correct answers. In this case, students will be able to identify one or more correct answers during the course assignment. In the rest of the tasks, students are asked to write their answers in short or complete terms, to answer, calculate or graphically, to complete the tables [4, P.31].

In the $1950 \mathrm{~s}$, OICs began to keep statistics on various education systems. The purpose of this statistic is to foresee the needs of industrialized countries in the training of qualified specialists through education planning. Apart from the economic interest in these statistics, they are also socially and politically relevant, and provide access to the necessary statistics to analyze issues of equality in education.

The initial approach of the OIC countries is focused on quantitative features, comparing government spending on education, ie government funding for education, and funding resources. Since 1992, these statistical reports have been published by the OIC in the form of a report entitled Education at a Glance [1, p.6]. Educational Evaluation Criteria developed by this OIC initiative have been extensively used in education other than education, including in the economic, socio-political and educational sectors $[3, \mathrm{p} .12]$.

\section{CONCLUSION}

As can be seen from the aforementioned descriptions, the PISA Assessment Survey is a study that covers a wide range of pragmatic general education. Education is the process of developing the young generation's outlook and personality. The basis of educational content is the connection of the world in which we live, with the language, the styles and models of natural sciences, and the mathematics.

\section{REFERENCES}

1. Antonietti, Jean-Philippe; Berweger, Simone; Biedermann, Horst; Brühwiler, Christian; Guignard, Ninon; Holzer, Thomas; Mariotta, Myrta; Moreau, Jean; Moser, Urs; Nicoli, Manuela; Nidegger, Christian; Ramseier, Erich; Zahner Rossier, Claudia: Bildungsmonitoring Schweiz, Neuchâtel u.a., 2005

2. Decree of the President of the Republic of Uzbekistan "On measures to radically improve the effectiveness of out-of-school education in the public education system"

3. https://www.pisa-tum.de/pisa-2018/

4. Freerk Huisken: Der „PISA-Schock“ und seine Bewältigung. Wieviel Dummheit braucht/verträgt die Republik? VSA-Verlag Hamburg 2005 